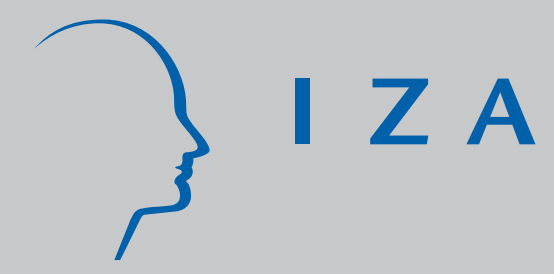

IZA DP No. 3957

The Gender Pay Gap for Private Sector Employees in Canada and Britain

Marie Drolet

Karen Mumford

J anuary 2009 


\title{
The Gender Pay Gap for Private Sector Employees in Canada and Britain
}

\author{
Marie Drolet \\ Statistics Canada \\ Karen Mumford \\ University of York \\ and IZA
}

\section{Discussion Paper No. 3957 \\ January 2009}

IZA
P.O. Box 7240
53072 Bonn
Germany

Phone: +49-228-3894-0

Fax: +49-228-3894-180

E-mail: iza@iza.org

\begin{abstract}
Any opinions expressed here are those of the author(s) and not those of IZA. Research published in this series may include views on policy, but the institute itself takes no institutional policy positions.

The Institute for the Study of Labor (IZA) in Bonn is a local and virtual international research center and a place of communication between science, politics and business. IZA is an independent nonprofit organization supported by Deutsche Post Foundation. The center is associated with the University of Bonn and offers a stimulating research environment through its international network, workshops and conferences, data service, project support, research visits and doctoral program. IZA engages in (i) original and internationally competitive research in all fields of labor economics, (ii) development of policy concepts, and (iii) dissemination of research results and concepts to the interested public.
\end{abstract}

IZA Discussion Papers often represent preliminary work and are circulated to encourage discussion. Citation of such a paper should account for its provisional character. A revised version may be available directly from the author. 


\section{ABSTRACT}

\section{The Gender Pay Gap for Private Sector Employees in Canada and Britain*}

This paper uses British and Canadian linked employer-employee data to investigate the importance of the workplace for the gender wage gap. Implementing a novel decomposition approach, we find high levels of unexplained wage inequality in the private sector of both countries, which is related to women receiving relatively lower wages within workplaces than do men. Whilst this inequality is partially offset by women, on average, receiving a workplace specific return which is relatively higher than that paid to men, a substantial and significant unexplained within workplace wage gap remains which is considerably higher in Britain than in Canada. The results are consistent with a prima facie argument that country-specific factors, such as the wage setting environment, are important determinants in explaining the relative size of the gender wage gap.

JEL Classification: J16, J0

Keywords: $\quad$ gender earnings gap, workplaces, Britain, Canada

Corresponding author:

Karen Mumford

Department of Economics and Related Studies

University of York

Heslington York YO10 5DD

United Kingdom

E-mail:kam9@york.ac.uk

\footnotetext{
* We are grateful to Z. Patak, K. Marchand, L. Marchand and Peter N. Smith for their insights and support. The authors also wish to thank anonymous referees and the participants at the BJIR Conference on Workplace Issues at the London School of Economics, March 14-15, 2008.
} 


\section{Introduction}

Gender wage gaps have been declining in most industrialized countries in the last three decades coinciding with the introduction of anti-discrimination legislation; higher levels of educational attainment among women; increases of women in non-traditional professional occupations; and more choices being made available to men and women both inside and outside the labour market (Blau and Kahn, 2007). Despite these gains, substantial earnings gaps have remained in Britain and Canada and initiatives aimed at promoting gender equality in the labour market remain high on the policy agenda in both countries.

The literature on gender wage inequality is well established (Altonji and Blank, 1999; Blau and Kahn, 2003). While there is some variation in the findings of these studies, (related to time periods, country-specific effects, measurement of earnings, and analytical populations to name a few), it is generally concluded that human capital differences alone do not explain the gender wage gap. The recent availability of employee-employer linked data has resulted in several studies which find that firms play an important role in explaining variations in individual earnings (Groshen 1991; Bronars and Famulari 1997; Abowd et al. 2004; Bayard et al. 2003). These studies confirm that after accounting for workers' human capital, job characteristics and workplace segregation, men typically earn more than women (Carrington and Troske, 1998; Drolet 2002; Mumford and Smith 2007).

International comparisons of gender pay differentials are rare, partly because institutional factors differ greatly across nations yet there exists an opportunity to improve our understanding of the how the labour market functions (Blau and Kahn, 2003; Olivetti and Petrongolo, 2008). A great strength in the use of linked employee-employer data for international comparisons is that many of the unobservable institutional factors expected to impact upon wages may operate through the potentially very important workplace (Blanchflower, 1998). 
While these factors may not be able to be measured directly, they can be captured by including workplace specific fixed effects in the analysis (Davies and Welpton, 2005). The growth in the number of highly detailed, linked employee and workplace data sets for different countries over the last two decades is now allowing these types of comparisons to take place (early examples include studies for Australia, Britain, Japan and France (Daly et al, 2006); for Australia and France (Meng and Meurs, 2004); and for Australia and Britain (Mumford and Smith, 2003). All of whom found substantial and significant effects associated with the workplace for men and women.

The objective of this paper to provide a comprehensive picture, circa 2003/4, of the role of the workplace in gender pay differentials in Britain and Canada. To meet our objective we show that pay differences between men and women are substantial and significant in both countries; explore multiple and complementary strategies to address the role of workplaces on the gender wage gap; and use decomposition techniques to apportion the gender wage differential to differences in workplace-specific fixed effects and in personal attributes. The paper is organized as follows. The next section briefly describes the institutional settings of wage determination in Britain and Canada. The data are described in Section 3. Sections 4 and 5 outline the determinants of earnings and our estimation techniques. The empirical results are presented in Section 6 and concluding remarks follow in Section 7.

\section{Labour market institutions of wage determination}

Britain and, its former colony, Canada share many common legal and cultural roots. Both countries are categorized by the OECD as having highly decentralized firm-by firm wage bargaining practices (Card et al. 2003, pages 247-251). Changes in the British system of wage determination since the 1970s have moved the countries closer in terms of regulatory processes. Canada experienced virtually no change in trade union membership while Britain 
witnessed a decline in both trade union density (from 50\% in 1980 to $24 \%$ in 1994 ) and in the percentage of the workforce covered by a collective agreement (from $70 \%$ in 1980 to $47 \%$ in 1994). In consequence, the two countries now have similar trade union membership and collective agreement rates, relative to paid employees (Card et al. 2003, table 1). Another important similarity between Britain and Canada is that low wage workers in both countries are protected by minimum wage legislation. Minimum wage legislation is more likely to impact on women since women are on general disproportionately employed in low paying jobs (Blau and Kahn, 2003).

A major difference between Canada and Britain is their adoption of comparable worth principles in wage legislation. The Equal Pay Act was passed in Britain in 1970 in recognition of women receiving lower pay than men. Whilst the Act included a broad concept of equity allowing for comparisons between jobs typically performed by women and jobs typically performed by men, the emphasis was on equal pay for equal work (Dickens, 2007). More recently, the Women and Work Commission was established (in 2004) to seek ways to tackle the remaining gender earnings gap. The Commission found that, whilst the causes of the current gender earnings gap were complex and interrelated, intrinsic amongst them was occupational segregation, lack of vocational qualifications, discrimination, and fewer job opportunities for women wanting to combine market employment with non-market family responsibilities (Women and Work Commission, 2006 pages x-xvi) . The British Government responded to these findings with the introduction of the Commission for Equality and Human Rights (which came into being on October $1^{\text {st }}, 2007$ ) and a range of policies predominantly targeted at increasing the occupation choices of women (via skill acquisition and broadening attitudes) and increasing their ability to cope with family and work commitments simultaneously (Department for Communities and Local Government, 2007). 
In Canada, the Act to Promote Equal Pay for Female Employees was passed in 1956 and prohibited employers from paying women less than men for doing the same work. The emphasis in this early legislation was also on equal pay for equal work. More recent initiatives aimed at promoting gender equality in the labour market are generally categorized in three main areas: pay equity, employment equity and family friendly policies. Pay equity legislation is directed at wage disparities arising from the lower pay of women's jobs with respect to comparably valued men's jobs within a specific workplace. The Pay Equity Act applies in Ontario, Manitoba, New Brunswick, Nova Scotia, Prince Edward Island and Quebec. However, only in Ontario and Quebec (the two largest provinces), does the legislation cover both the private and public sector. In Manitoba, New Brunswick, Nova Scotia and Prince Edward Island the Act applies formally only to the public sector. The Employment Equity Act (1995) aims to remove barriers that limit women's representation in male-dominated occupations for reasons unrelated to qualifications and/or ability. Finally, the

introduction of family-friendly policies (such as job-protected maternity leave, flexible work hours, subsidized day-care) aimed at balancing work-family, encourages the labour market participation of women with young children. The existence and persistence of a sizeable gender wage gap is often viewed as the driving force behind gender equality policies. These policies attempt to reduce gender pay differentials by promoting equal opportunity, reducing segregation and by re-assessing the comparable value of women's work. But the efficacy of these policy prescriptions are often passionately debated in policy circles, among academics and in the media.

\section{Data.}

Comparable empirical evidence is a necessity when considering an international study of gender pay gaps. The Canadian and British data used in this study are drawn from 'sister 
surveys' that include many overlapping questions and feature a similar surveying approach. They are, however, not identical surveys and important differences exist.

\section{Workplace and Employee Survey}

The Canadian data are drawn from the 2003 Workplace and Employee Survey (WES) ${ }^{2}$. The target population of employers is all business locations operating in Canada that have paid employees in March with the exception of those employers operating in (i) Yukon, Nunavut and the Northwest Territories; and (ii) crop and animal production; hunting, fishing and trapping; private household; religious organizations; and public administration. The target population of employees is all employees working or on paid leave in March and who receive a Customs Canada and Revenue Agency T4 tax slip. In other words, the WES is representative of employers and their workers in the private, non-agricultural sector of the Canadian economy. The lack of data on public sector workplaces and employees is an

unfortunate limitation of the WES data set. ${ }^{3}$ The public sector employs a large proportion of the total workforce in both Canada and Britain (19\% and 20\% respectively in 2004) and gender pay gaps in the public sector would be expected to be lower in both countries (see Meuller, 1998 for Canada and Disney and Gosling, 2007 for Britain). The 2003 WES collected data from 6,565 workplaces and 20,834 workers.

The WES has a stratified two-stage sample design: first, workplaces are selected from a frame provided by the Business Register and then stratified by industry, region and size (Phillips, 2004). In the second stage, the employee component, respondents are randomly selected based on lists of employees made available to interviewers by the selected workplaces. 


\section{Workplace Employee Relation Survey 2004}

The Workplace Employee Relations Survey 2004 (WERS) is a nationally representative survey of workplaces in Britain with 5 or more employees ${ }^{4}$. WERS also has a stratified twostage sample design (Purdon and Pickering, 2001). Face-to-face interviews were conducted with a senior manager (with day-to-day responsibility for employee relations) in selected workplaces. At those workplaces responding to the manager survey, a questionnaire was presented to 25 randomly selected employees (in workplaces with more than 5 employees) or to all employees (in workplaces with fewer than 26 employees). The 2004 WERS collected information from 22,451 workers in 1,733 of workplaces.

\section{Analytical sample}

The data sets are not identical in population coverage. Excluding public sector workplaces in WERS to match the Canadian WES sample, excluding workplaces with fewer than 5 employees in WES to match the British WERS sample, and retaining workers with complete information leaves an analytical sample for Britain of 14,272 employees and 18,837 workers in Canada.

Every attempt was made to harmonize variable concepts between the WERS and the WES. Table A1 in the Statistical Appendix provides the variable definitions used in the paper. Sampling weights are used to calculate the empirical results that follow. For WERS, weights allowing for stratification and clustering in the private sector are provided by the data suppliers (Purdon and Pickering, 2001). The WES portion of the analysis uses bootstrap techniques in the calculation of its standard errors thus accounting for the non-independence of worker observations (i.e. workers in the same location) and the complex survey design (Phillips, 2004). ${ }^{5}$ 
Macroeconomic conditions in the countries during the period of study (2003-4) were also comparable. Business cycle indicators suggest that in 2003-4 both economies were growing strongly (GDP growth per capita ranged from 2.3\% in Britain to 3.3\% in Canada), and that unemployment rates were relatively low (at 5\% the UK rate was below the OECD average of $6.9 \%$, whilst the Canadian unemployment rate was closer to $7.5 \%$ ).

\section{Characteristics of the British and Canadian workforces}

Table 1 provides selected summary statistics for private sector workers in Canada and Britain (detailed variable definitions and additional descriptive statistics are provided in the Appendix). Working part-time is more common amongst female employees in Britain than in Canada. Of the OECD member countries, in 2004 the United Kingdom had one of the highest proportions of part-time working amongst women (OECD, 2005 page 253), whereas the proportion of women working part-time in Canada is close to the OECD average (of 25.4\%).

The average age of male employees is the same in the two countries; the women tend to be a little younger, especially in Britain. Measures of work experience are usually assumed to be positively related to wages for several reasons, not least of which is the ability to acquire skills over the time period the employee has spent working (Becker, 1962). Since the WERS survey does not gather information on actual experience, age and age-squared is used instead. It is common to find that earnings increase with age at a decreasing rate. The results need to be interpreted with caution if women are more likely than men to have taken time out of the labour market, age may not accurately reflect the relationship between work experience and earnings (Regan and Oaxaca, 2009). It is possible to more fully address different earnings gaps between younger and older employees by dividing the data into sub-samples according to the age of the worker. 
Table 1. Selected summary statistics for private sector employees in Britain and Canada.

\begin{tabular}{ccccccc}
\multicolumn{3}{c}{ Britain } & & \multicolumn{3}{c}{ Canada } \\
\cline { 1 - 2 } \cline { 5 - 7 } Men & Women & Gap & & Men & Women & Gap \\
$(1)$ & $(2)$ & $(3)$ & & $(1)$ & $(2)$ & $(3)$
\end{tabular}

Percent of private sector workers who are:

Part-time

Married

8.938 .6

$66.5 \quad 63.4$

Average age (years)

$40.4 \quad 38.8$

$-29.7$

3.1

$6.9 \quad 21.6$

$-14.7$

Average age (years)

$\%$ of all private sector workers who are university graduates

$26.3 \quad 19.5$

1.6

72.0

64.5

7.5

$\%$ of young workers (less than 40 years old) who are graduates

31.

$\%$ of prime age workers (aged 40-49 years) who are graduates

31.1

19.5

6.8

40.4

40.0

0.4

$\%$ of mature workers (aged 50 plus years) who are graduates

25.7

25.3

5.8

22.7

$23.6 \quad-0.9$

17.5

16.5

23.1

26.6

$-3.5$

17.5

9.2

9.2

22.2

20.9

1.3

Percent of private sector workers employed in:

Management

$16.9 \quad 10.1$

8.3

22.4

21.4

1.0

Clerical

Sales and services

$7.7 \quad 27.1$

6.8

16.5

8.7

7.8

6.0

18.7

$-19.4$

7.2

21.8

log of average hourly earnings for:

all private sector workers

2.199

1.952

$-12.7$

3.3

11.7

$-8.4$

young workers (less than 40 years old)

prime age workers (aged 40-49 years)

Sources: British Workplace Employee Relations Survey 2004 and the Canadian Workplace and Employee Survey 2003.

About one in four private sector workers have a university degree or post-graduate qualification (column one of Table 1). Rapidly rising levels of educational attainment among young women over the past two decades have helped to narrow the overall gender difference in educational attainment in both Britain and Canada. In Canada, there is little difference in amongst the older age groups (comparing columns 3 and 6 of Table 1). In contrast, gender differences in higher levels of educational attainment are more common in Britain (columns 1 and 2). It should be noted that wages differ by fields of study and that many fields of study continue to be dominated by either men or women. One significant caveat is that, whilst there has been notable changes in some discipline areas (such as biology, medicine, management and law), men and women tend to choose traditional disciplines; a factor that is not accounted 
for in this study and this choice may also explain part of the gender differences in earnings (Drolet, 2002).

The gender differences in occupational distributions were relatively consistent between the two countries and conformed to a priori expectations (Bergmann, 1971; Baker and Fortin, 2001). In both countries, men were more likely to be in managerial, craft or operative positions while women were more likely to be employed as clerks or in sales positions. (Additional summary statistics are presented in appendix tables A2 and A3.)

\section{Earnings and its determinants}

The well-established human capital model is adopted here as the theoretical basis for the earnings function (Becker, 1962). At the employee level, the human capital model predicts that wages increase with measures of accumulated skills such as formal education and training. The earnings function is augmented with the inclusion of other explanatory variables capturing individual employee characteristics such as demographic variables (including age, the presence of dependent children, marital status, ethnic identification, and physical disability); the nature of the employment contract (being a permanent employee, trade union membership, working part-time and current job tenure); and the worker's occupation. (Variable definitions and descriptive statistics are provided in the Appendix.)

\section{Measuring earnings}

For British workers, hourly earnings are calculated for each employee by dividing their usual gross (before tax and other deductions) weekly wages (including overtime payments) by the hours they usually work each week (including any overtime and extra hours). The WERS data do not give the actual value of gross weekly wages but rather the interval to which the wage belongs for each sampled worker, there are 14 bands. In the regression analysis below, the 
mid-point of the interval is used as the measure of usual weekly wages (some possible implications of this banding are discussed further with estimation results in Section 6 below). Usual hours worked is a continuous measure. The subsequent hourly wage measure is the ratio of weekly wages to usual hours and is therefore continuous. Any employees showing an hourly rate of pay below $£ 1$ or above $£ 100$ are excluded from the British dataset.

For Canadian workers, total compensation is based on usual wages and salaries before taxes including any other earnings (i.e. tips, overtime). WES respondents were allowed to report different bases of pay (i.e. hourly, weekly, yearly etc.) and were subsequently converted to an hourly wage rate based on their reported weekly hours and weeks worked.

\section{Gender differences in hourly wages}

Gender differences in earnings are remarkably similar in the private sector for both Britain and Canada. Men typically earn over 20\% more than the average hourly wage rate of women (24.7 log points, lp, in Britain and 23.3 lp in Canada, see the final panel of Table 1). These gender differences in earnings vary in magnitude for different age groups. The gender wage gap is smallest among young workers (those aged below 40 years) and largest among mature workers (those aged 50 years and above).

The smaller gender wage gap among young workers may be partially attributable to young men and women having more similar skills and experience. The fact that the pay gap is larger among older workers may reflect larger gender differences in educational attainment, in career opportunities and upward mobility, and the greater possibility of these women having experienced career interruptions, with long withdrawals from the labour force and shorter current job tenure (Regan and Oaxaca, 2009). This observation may have interesting implications for the longer term earnings profiles of young workers and the overall gender wage gap. As older workers retire and younger cohorts enter the labour force, the long-run implication may be a reduction in the overall gender wage gap, ceteris paribus. As discussed 
above, it is possible to more fully address different earnings gaps between younger and older employees by dividing the data into sub-samples according to the age of the worker; this is explored in the empirical analysis below.

\section{Estimating earnings.}

Using semi-logarithmic wage equations, the earnings equation is estimated using ordinary least squares (OLS) as:

$$
W_{i}=\alpha+X_{i} \beta+F_{i} \gamma+\varepsilon_{i}
$$

where $W_{i}$ is the natural $\log$ of the wage for worker $i ; \alpha$ is an intercept term; $X_{i}$ is a vector of individual-specific regressors capturing the characteristics of worker $i$ expected to impact on wages; $\beta$ is a vector of estimated slope coefficients for the individual-specific characteristics; the variable $F_{i}$ indicates whether the worker is female and its corresponding coefficient $\gamma$ captures the impact of being a woman relative to being a man; $\varepsilon_{i}$ is a residual term. The coefficient estimates, $\beta$ and $\gamma$, can be interpreted as the approximate percentage change in wages for a one unit change in the explanatory variable. In this model, the slope coefficients, the $\beta \mathrm{s}$, are constrained to be the same for men and women, analogous to the fully pooled model used by Bayard et al. (2003). ${ }^{6}$

\section{Estimation strategy with workplace specific fixed effects}

As discussed above, multiple workers are observed for each workplace in the WES and WERS samples used here. A useful technique to explore the extent of the workplace having a common impact on the earnings of all of those who are employed there is to use a workplace specific fixed effect (or within estimator) model. ${ }^{7}$ Workplace-specific fixed effects are allowed for by re-estimating equation (1) using a fixed effects (FE) model:

$$
W_{i j}=\alpha+K_{j} \delta+X_{i j} \beta+F_{i} \gamma+\varepsilon_{i j}
$$


where $K$ is an indicator variable for each workplace $j$ and $\delta$ captures the workplace specific fixed effect.

\section{Estimation results}

Results of the OLS estimation of the earnings functions are presented in Table 2; columns 1 and 2 for Britain, and 5 and 6 for Canada. Analogous results for the fixed effects estimation are provided in columns 3 and 4 for Britain, and 7 and 8 for Canada. Total raw wage gaps are also provided for each of the samples in the final row; these are simply the unadjusted differences in the average wages of men and women that we observe in the data. Of particular importance to this study, after allowing for the inclusion of a broad range of explanatory variables in the earnings functions ${ }^{8}$, a significant and substantial unexplained gender pay gap remains in both countries (15.5 lp in Britain and $18.3 \mathrm{lp}$ in Canada). These unexplained gender wage gaps are $62.8 \%$ of the total raw gap in Britain and $78.5 \%$ of the total raw gap in Canada.

Including workplace fixed effects in the analysis is associated with a sizeable reduction in these unexplained gender pay gaps (from 15.5 lp to $10.6 \mathrm{lp}$ in Britain and from 18.3 lp to 11.0 lp in Canada). The unexplained pay gap is now $42.9 \%$ of the total raw pay gap in Britain and $47.2 \%$ of the total raw gap in Canada. Or, in other words, within workplaces the unexplained gender pay gaps are about a third smaller in both countries (a little more in Canada than in Britain). 
Table 2. Earnings functions for private sector employees in Britain and Canada.

Britain

\begin{tabular}{|c|c|c|c|c|c|c|c|c|c|}
\hline \multirow{3}{*}{ log hourly pay } & \multicolumn{4}{|c|}{$\begin{array}{c}\text { with workplace } \\
\text { effects }\end{array}$} & \multirow{3}{*}{ log hourly pay } & \multicolumn{2}{|c|}{ OLS } & \multicolumn{2}{|c|}{$\begin{array}{c}\text { with workplace } \\
\text { effects }\end{array}$} \\
\hline & Coef. & Std Err & Coef. & Std Err & & Coef. & Std Err & Coef. & Std Err \\
\hline & $(1)$ & $(2)$ & (3) & (4) & & (5) & (6) & (7) & (8) \\
\hline female & -0.155 & 0.012 & -0.106 & 0.010 & female & -0.183 & 0.025 & -0.110 & 0.011 \\
\hline age & 0.042 & 0.003 & 0.031 & 0.003 & age & 0.034 & 0.007 & 0.024 & 0.003 \\
\hline age squared & -0.448 & 0.037 & -0.317 & 0.031 & age squared & -0.353 & 0.083 & -0.237 & 0.036 \\
\hline $\begin{array}{l}\text { training } \\
\text { education } \\
\text { (not recognised omitted) }\end{array}$ & 0.006 & 0.002 & 0.004 & 0.001 & $\begin{array}{l}\text { training } \\
\text { education } \\
\text { (not recognised omitted) }\end{array}$ & 0.0007 & 0.001 & 0.000 & 0.0003 \\
\hline intermediate secondary (lower) & 0.075 & 0.015 & 0.067 & 0.013 & high school & 0.105 & 0.043 & 0.031 & 0.019 \\
\hline intermediate secondary (upper) & 0.127 & 0.013 & 0.084 & 0.011 & trade & 0.175 & 0.048 & 0.065 & 0.021 \\
\hline higher secondary (lower) & 0.142 & 0.022 & 0.101 & 0.018 & some post secondary & 0.196 & 0.050 & 0.051 & 0.020 \\
\hline higher secondary (upper) & 0.240 & 0.021 & 0.185 & 0.016 & college & 0.264 & 0.048 & 0.086 & 0.019 \\
\hline degree & 0.312 & 0.018 & 0.205 & 0.014 & university degree & 0.374 & 0.053 & 0.162 & 0.021 \\
\hline \multirow[t]{2}{*}{ postgraduate } & 0.397 & 0.024 & 0.252 & 0.019 & post graduate & 0.501 & 0.076 & 0.289 & 0.026 \\
\hline & & & & & unknown & 0.108 & 0.084 & 0.033 & 0.034 \\
\hline youngest dep. child 0-4 & 0.037 & 0.013 & 0.016 & 0.011 & youngest dep. child 0-4 & 0.041 & 0.036 & 0.023 & 0.015 \\
\hline youngest dep. child 5-11 & 0.001 & 0.015 & 0.013 & 0.012 & youngest dep. child 5-11 & 0.021 & 0.032 & 0.001 & 0.014 \\
\hline youngest dep. child 12-18 & -0.030 & 0.013 & -0.010 & 0.012 & youngest dep. child 12-18 & 0.016 & 0.035 & 0.007 & 0.014 \\
\hline married & 0.053 & 0.010 & 0.046 & 0.008 & married & 0.071 & 0.028 & 0.048 & 0.011 \\
\hline disabled & -0.019 & 0.014 & -0.003 & 0.012 & disability & -0.042 & 0.043 & -0.004 & 0.015 \\
\hline visible minority & -0.055 & 0.021 & -0.075 & 0.017 & visible minority & -0.114 & 0.050 & -0.107 & 0.018 \\
\hline permanent contract & 0.038 & 0.022 & 0.030 & 0.020 & permanent contract & 0.041 & 0.090 & 0.051 & 0.027 \\
\hline part-time & -0.068 & 0.018 & 0.057 & 0.016 & part-time & -0.101 & 0.040 & -0.041 & 0.015 \\
\hline trade union member & 0.075 & 0.013 & 0.014 & 0.011 & trade union member & 0.072 & 0.028 & -0.065 & 0.016 \\
\hline tenure & 0.015 & 0.005 & 0.006 & 0.004 & tenure & 0.015 & 0.030 & 0.002 & 0.010 \\
\hline tenure squared & 0.0004 & 0.001 & 0.001 & 0.000 & tenure squared & 0.886 & 2.267 & 1.085 & 0.796 \\
\hline \multicolumn{5}{|l|}{ occupations (clerical omitted) } & \multicolumn{3}{|c|}{ occupations (clerical omitted) } & & \\
\hline managerial & 0.255 & 0.020 & 0.326 & 0.015 & managers & 0.423 & 0.051 & 0.469 & 0.019 \\
\hline professional & 0.278 & 0.023 & 0.262 & 0.020 & professionals & 0.348 & 0.044 & 0.337 & 0.018 \\
\hline technical & 0.143 & 0.017 & 0.148 & 0.014 & technical trade & 0.082 & 0.030 & 0.141 & 0.015 \\
\hline craft & -0.076 & 0.021 & 0.039 & 0.019 & market sales & -0.176 & 0.053 & 0.062 & 0.025 \\
\hline personal & -0.277 & 0.024 & -0.094 & 0.024 & production & -0.077 & 0.058 & 0.006 & 0.024 \\
\hline sales & -0.269 & 0.021 & -0.071 & 0.019 & & & & & \\
\hline operative & -0.210 & 0.021 & -0.100 & 0.016 & & & & & \\
\hline unskilled & -0.364 & 0.020 & -0.176 & 0.017 & & & & & \\
\hline constant & 1.022 & 0.059 & 1.189 & 0.053 & constant & 1.633 & 0.157 & 2.036 & 0.067 \\
\hline R-squared & 0.478 & & 0.670 & & R-squared & 0.523 & & 0.800 & \\
\hline No. observations & 14272 & & 14272 & & No. observations & 18837 & & 18573 & \\
\hline Raw (unadjusted) wage gap & 0.247 & & & & & 0.233 & & & \\
\hline
\end{tabular}

Sources: British Workplace Employee Relations Survey 2004 and the Canadian Workplace and Employee Survey 2003.

Note: variable definitions are not identical across the countries; see Table A1 in the appendix for fuller definitions. 
By comparing the estimated parameters for the earnings functions with workplacespecific fixed effects (columns 3 and 7) and those without workplace effects (columns 1 and 5), implications of the workplace effect in the wage determination process becomes more evident. Including the workplace in the analysis is associated with lower returns to most human capital variables in both countries. For example, Canadian workers with a university degree earn 37.4\% more than workers with no education (column 5). Once we control for the workplace, Canadian workers with a university degree earn $16.2 \%$ more than workers with no education (column 7). Comparable figures for Britain are 20.5\% allowing for workplace effects and $31.2 \%$ without. This provides some evidence that part of the variation in individual earnings attributable to, for example, differing levels of education may arise because high-wage workplaces disproportionately employ high skilled workers in both countries. ${ }^{9}$ In the extreme case of part-time employees in Britain the estimated coefficients indicate a change from a negative to a positive association with wages after the introduction of workplace fixed effects in the model. A similar result was found for Australia by Meng and Meurs (2004) and is consistent with part-time employees being strongly segregated into low paying workplaces within which they are relatively highly paid (Connolly and Gregory, 2008; Manning and Petrongolo, 2008).

Similar analysis can be carried out for different age groups by dividing the sample accordingly, the estimated gender wage gaps are reported Table 3 (full results are available from the authors). Standard errors are reported immediately below the coefficient estimates in Table 3; in each case the reported gender wage effect is strongly significant. Total raw wage gaps are also provided for each of the samples.

Reading down the columns in Table 3, as discussed in section 4 above, the raw (unadjusted) gender pay gaps are lower amongst the young than the older (prime or mature age) workers in Britain, indeed they are almost half the size. These relative differences are not 
as sizable in Canada but they are still substantial. The unexplained female wage gap in the OLS results (columns 1 and 3) is considerably lower amongst younger employees in both Britain and Canada.

Table 3. Estimated gender coefficients.

\begin{tabular}{ccccc} 
& \multicolumn{2}{c}{ Britain } & \multicolumn{2}{c}{ Canada } \\
& $\begin{array}{c}\text { Without } \\
\text { Workplace } \\
\text { effects }\end{array}$ & $\begin{array}{c}\text { With } \\
\text { Workplace } \\
\text { effects }\end{array}$ & $\begin{array}{c}\text { Without } \\
\text { Workplace } \\
\text { effects }\end{array}$ & $\begin{array}{c}\text { With } \\
\text { Workplace } \\
\text { effects }\end{array}$ \\
\cline { 2 - 6 } Panel (1) & $(1)$ & $(2)$ & $(3)$ & (4)
\end{tabular}

Young workers (aged < 40 years)

Raw wage gap

\begin{tabular}{llll}
\multicolumn{2}{c}{0.168} & & \multicolumn{2}{c}{0.206} \\
-0.094 & -0.077 & -0.139 & -0.088 \\
0.014 & 0.012 & 0.034 & 0.018
\end{tabular}

Std error 0.014

Prime aged workers (aged 40-49 years)

Raw wage gap

Female Coefficient

Std error

$-0.217$

0.336

$-0.128$

0.020

0.320

$-0.218$

0.026

$-0.151$

0.024

Mature workers (aged 50 years and over)

Raw wage gap

Female Coefficient

Std error
0.275

$\begin{array}{ll}-0.206 & -0.136 \\ 0.041 & 0.022\end{array}$

0.022

0.271

$-0.207 \quad-0.09$

Sources: British Workplace Employee Relations Survey 2004 and the Canadian Workplace and Employee Survey 2003. Dependent variable is log hourly wages. Independent variables are listed in Tables A4 and A5 of the Appendix, they include age, age squared, training, education controls, marital status, age of youngest dependent child, visible minority status, disability, permanent contract, trade union membership, tenure, tenure squared, parttime and occupation controls. Note: variable definitions are not identical across the countries, see Table A1 in the Appendix for fuller definitions.

Including workplace specific fixed effects in the analysis (columns 2 and 4) is again associated with a substantial reduction in the within workplace unexplained gender pay gap in both countries for all three age groups being considered. Indicating that within each age band, women face a more equal pay structure within the workplace; this is particularly true of more mature women relative to more mature men in Canada. Given the size of the standard errors, there is little significant remaining difference within the workplace in the estimated female 
pay penalty for the various age groups after accounting for the impact of the workplace in Canada (reading down columns 2 and 4).

To summarise, the OLS decomposition results (without the workplace effects) show that for private sector employees in both Britain and Canada (and within the age groups), the portion of the gender wage gap attributable to differences in the returns that men and women receive for the same characteristic (the unexplained component) far outweigh the portion of the gender wage gap attributable to differences in the characteristics men and women bring to the labour market (the explained component). A larger fraction of the pay gap, however, is due to the gender differential in endowments of characteristics in Britain than in Canada. Furthermore, the unexplained component of the gender wage gap declines substantially with the introduction of workplace specific-effects. This is true in both Britain and Canada and this effect is stronger amongst older workers. Nevertheless, a substantial portion of the gender wage gap in both countries and within all three age groups is not explained by individual characteristics and workplace effects.

So far the relationship between the workplace and earnings has been assumed to be the same for both the men and the women who work there. This may not be the case, estimating separate earnings functions for men and women allows for the examination of the relative contribution of the workplace to the gender pay gap in more detail. Gender specific workplace fixed effects are allowed for by re-estimating equation (2) using a fixed effects (FE) model for males $(m)$ and for females $(f)$ :

$$
\begin{aligned}
& W_{i j}^{m}=\alpha^{m}+X_{i j}^{m} \beta^{m}+\delta_{j}^{m}+\varepsilon_{i j}{ }^{m} \\
& W_{i j}^{f}=\alpha^{f}+X_{i j}{ }^{f} \beta^{f}+\delta_{j}^{f}+\varepsilon_{i j}{ }^{f}
\end{aligned}
$$

In particular, estimating separate earnings functions for men and women allows for the estimated returns to characteristics $(\hat{\beta})$ and the workplace specific premium $(\hat{\delta})$ to differ across the genders. 
Decomposing the gender pay gap in Britain and Canada.

The traditional Oaxaca approach decomposes the mean gender wage gap into two components: the explained portion attributable to differences in the observable characteristics men and women bring to the labour market (such as education or training) and the portion that cannot be explained by such differences (Oaxaca 1973; and Blinder 1973). Oaxaca and Ransom (1999) discuss identification difficulties in providing more detailed decompositions. Yun (2005) provides examples of how these identification problems may be overcome via a normalized regression (or 'averaging approach). A rare early empirical application of such a detailed decomposition is provided by Meng and Meurs (2004). A Yun ‘averaging’ approach is adopted here to decompose the gender earnings gap into three components: the characteristics or 'explained' effect, $\left(\bar{X}_{m}-\bar{X}_{f}\right) \hat{\beta}_{m}$; the returns or 'unexplained' effect, $\left(\hat{\beta}_{m}-\hat{\beta}_{f}\right) \bar{X}_{f}$; and the workplace effect, $\hat{\delta}_{m}-\hat{\delta}_{f}$. It is this apportioning of the third component, the workplace effects, of the earnings gap that is of particular interest here. As discussed above, within workplaces, wages may be affected by a range of factors (such as the type of wage bargaining and/or the presence of discrimination) that may impact differently on men and women.

Decomposition results of the fixed effects estimation of the gender specific earnings functions are presented in Table 4. On average, the total raw gender wage gap are 24.7 and $21.2 \log$ points (lp) for Britain and Canada, respectively. ${ }^{10}$ The differences in observable characteristics (the explained) component can now be seen to account for $3.4 \%$ and $34.2 \%$ of the total gender wage gap in Britain and Canada respectively. This explained component for Britain is low, however, it is consistent with that found for the earlier (1998) wave of the WERS data (Mumford and Smith, 2007). 
Table 4. Decomposition results, separating out the workplace effect.

\begin{tabular}{|c|c|c|}
\hline & Britain & Canada \\
\hline & $\begin{array}{c}\text { Gap in log wage points } \\
\text { (1) }\end{array}$ & $\begin{array}{l}\text { Gap in log wage points } \\
\text { (3) }\end{array}$ \\
\hline Total raw (unadjusted) wage gap & 0.247 & 0.212 \\
\hline differences in characteristics (explained) & 0.008 & 0.073 \\
\hline$\%$ explained & $3.4 \%$ & $34.4 \%$ \\
\hline differences in returns (unexplained) & 0.323 & 0.171 \\
\hline$\%$ unexplained & $130.7 \%$ & $80.6 \%$ \\
\hline Workplace effects & -0.084 & -0.310 \\
\hline$\%$ workplace effect & $-34.1 \%$ & $-14.6 \%$ \\
\hline
\end{tabular}

On average, the impact of the workplace can now be seen to narrow the gender wage gap by $14.6 \%$ in Canada and $34.1 \%$ in Britain. Similar results for comparable data sets have been found for France, 15.9\%, and Australia, 48.8\% (Meng and Meurs, 2004 page 197). This is an across workplace (rather than within workplace) effect which is perhaps counterintuitive. Allowing for men and women to have differing rates of return by estimating separate wage equations reveals that (after allowing for those individual characteristics expected to be associated with pay) at each workplace women receive a workplace specific return which is, on average, relatively higher than that paid to men. Or, in other words, gender specific features of the workplace (which could include pay policies) serve to reduce the size of the gender pay gap. This result is consistent with the aggregate (across gender) workplace effect found for the pooled estimation results reported above: the positive gender specific workplace effect on women's relative wages is swamped by women having substantially lower pay relative to men within workplaces. Results in Table 4 indicate that 
this is indeed the case. Britain has a larger portion of the total wage gap attributable to differences in returns (unexplained) within workplaces than does Canada (130.7\% compared to $80.6 \%)$. There is, however, considerable unexplained gender wage inequality within workplaces for both countries; placing Canada above France (at 58.2\%) but below Australia (at 108.5\%), with Britain measuring the highest (Meng and Meurs, 2004 page 197).

The finding that within workplace gender pay inequality is substantially lower for private sector employees in Canada than in Britain is consistent with a prima facie argument that Pay Equity legislation, with its criteria of within workplace comparable worth across genders, is having an impact in Canada. Nevertheless, equal pay legislation is far from fully effective in either country (as indicated by both countries exhibiting high levels of unexplained gender wage inequality), suggesting a need to further concentrate enforcement of this legislation on within workplace pay inequality.

\section{Concluding remarks}

Using linked employee-employer data, this paper considers the role of workplaces in a study of gender pay differentials for private sector employees in Britain and Canada. Total pay differences between men and women in the private sector economy are found to be similar, substantial and significant in both countries (at 24.7 log points in Britain and 23.3 log points in Canada).

High levels of unexplained gender wage inequality are found in both countries, which are related to women receiving relatively lower wages within workplaces than do men. Whilst this inequality is partially offset by women, on average, receiving a workplace specific return which is relatively higher than that paid to men, a substantial and significant unexplained within workplace wage gap remains which is considerably higher in Britain than in Canada. The results are consistent with a prima facie argument that Pay Equity legislation, with its 
criteria of within workplace comparable worth across genders, is having an impact on gender wage differentials in Canada. Equal pay legislation is, however, found to be far from fully effective for private sector employees in either country.

\section{References}

Abowd, J. Haltiwanger, J. and Lane, J. (2004). Integrated longitudinal employee-employer data for the United States. American Economic Review, Papers and Proceedings 94(2): $224-229$.

Altonji, J.G. and Blank, R. (1999). Race and Gender in the Labor Market in Ashenfelter, O. and Card, D. (eds.) Handbook of Labor Economics. Elsevier Science B.V, Amsterdam.

Baker, M. and Fortin, N.M. (2001). Occupational gender composition and wages in Canada, 1987-1988. Canadian Journal of Economics 34(2): 345-376.

Bayard, K., Hellerstein, J., Neumark. D. and Troske, K. (2003). New evidence of sex segregation and sex differences in wages from matched employee-employer data. Journal of Labor Economics. 21: 887-922.

Becker, G.S. (1962). Investment in human capital: A theoretical analysis. The Journal of Political Economy 70(5), 9-49.

Bergmann, B.R. 1971. Occupational segregation, wages and profits when employers discriminate by race or sex. Eastern Economic Journal. 1:103-110.

Blanchflower, D. (1998). International comparisons, Rapporteur report to an international symposium on linked employer-employee data. Monthly Labor Review 121(7): 59-60.

Blau, F.D. and Kahn, L.M. (2003). Understanding international differences in the gender pay gap. Journal of Labor Economics 21: 106-144.

Blau, F. and Kahn, L. (2007). The gender pay gap. The Economist Voice 4(4) Article 5. $\mathrm{http} / / \mathrm{www} /$ bepress.com/ev/vol14/iss4/art5.

Blinder, A. (1973). Wage Discrimination: Reduced Form and Structural Estimates. Journal of Human Resources 8; 436-55.

Bronars, S.G. and Famulari, M. (1997). Wage, tenure, and wage growth variation within and across establishments. Journal of Labor Economics 15(2): 285-317.

Carrington, W.J. and Troske, K. (1998). Sex segregation in U.S. manufacturing. Industrial and Labor Relations Review 51(3):445-64.

Card, D. Lemieux, T., and Riddell, C. (2003), Unions and the wage structure in John T. Addison and Claus Schnabel (eds.) The International Handbook of Trade Unions, Cheltenham: Edward Elgar, pp. 246-92.

Connolly, S. and Gregory, M. (2008.) Moving down? Women's part-time work and occupational change in Britain 1991-2001. The Economic Journal 118, F52-76.

Daly, A. Kawaguchi, A. Meng, X. and Mumford, K. (2006). The gender wage gap in four countries: A rehearsal of the Gregory contribution. Economic Record 82(257): 165176.

Davies, R. and Welpton, D. (2005). Linking the Annual Survey of Hours and Earnings to the 2004 Workplace Employment Relations Survey. A technical discussion with an illustrative analysis of the gender pay gap. WERS 2004 Information and Advice Service Technical Paper No. 3

Dickens, L. (2007). The road is long: Thirty years of equality legislation in Britain. British Journal of Industrial Relations 45(3): 463-494. 
Deaton, A. (1998). The Analysis of Household Surveys. A Microeconometric Approach to Development Policy. World Bank. John Hopkins University Press, Baltimore.

Disney, R. and Gosling, A. (2007). Changing public sector wage differentials in the UK. Mimeo, University of Nottingham.

Drolet, M. (2002). Can the workplace explain Canadian gender pay differentials? Canadian Public Policy 28: S41-S63.

Department for Communities and Local Government. (2007). Towards a fairer future, Implementing the Women and Work Commission Recommendations. Department for Communities and Local Government Publications, UK.

Groshen, E.L. (1991). The structure of male/female wage differential: Is it who you are, what you do, or where you work? Journal of Human Resources 26:457-72.

Manning, A. and Petrongolo, B. (2008.) The part-time pay penalty for women in Britain. Economic Journal 118, F28-51.

Meng, X. and Meurs, D. (2004). The gender earnings gap: Effects of institutions and firms A comparative study of French and Australian private firms, Oxford Economic Papers 56: 189-208.

Mueller, R.E. (1998). Public-private sector wage differentials in Canada: evidence from quantile regressions. Economics Letters 60(2); 229-235.

Mumford, K., and Smith, P.N. (2003). Determinants of current job tenure: A cross country comparison. The Australian Journal of Labour Economics 6(4): 597-608.

Mumford, K., and Smith, P.N. (2007). The gender earnings gap in Britain. Manchester School 75(6); 653-672.

Oaxaca, R.L. (1973). Male Female Wage Differentials in Urban Labor Markets. International Economic Review 14(3); 693-709.

Oaxaca, R. and Ransom, M. (1999). Identification in detailed wage decompositions. Review of Economics and Statistics 81(1): 154-157.

Olivetti, C. and Petrongolo, B. (2008). Unequal pay or unequal employment? A cross-country analysis of gender gaps. Journal of Labor Economics 26: 621-654.

OECD (2005) Employment Outlook, OECD, Paris.

Phillips, O. (2004). Using bootstrap weights with Wes Var and SUDAAN. Statistics Canada. The Research Data Centres Information and Technical Bulletin 1(2): 6-25.

Purdon, S. and Pickering, K. (2001). The use of sampling weights in the analysis of the 1998 Workplace Employee Relations Survey. National Centre for Social Research Mimeo, July 2001.

Regan, T. and Oaxaca, R. (2009). Work experience as a source of specification error in earnings models: Implications for gender wage decompositions. Journal of Population Economics, 22(2): 463-499.

Stewart, M. 1983. On least square estimation when the dependent variable is grouped. Review of Economic Studies 50(4): 737-753.

Women and Work Commission. (2006). Shaping a Fairer Future. Available from http://www.equalities.gov.uk/pdf/Shaping\%20a\%20Fairer\%20Future\%20report.pdf

Yun. M. (2005). A simple solution to the indentification problem in wage decompositions. Economic Inquiry 43(4): 766-772. 


\section{Endnotes.}

${ }^{1}$ Marie Drolet is a Senior Research Economist with the Business and Labour Market Analysis Division at Statistics Canada (email: marie.drolet@statcan.ca). Karen Mumford is Professor of Economics in the Department of Economic and Related Studies, University of York (email: kam9@york.ac.uk). We are especially grateful to Z. Patak, K. Marchand, L. Marchand and Peter N. Smith for their insights and support. The authors also wish to thank the anonymous referees and the participants at the BJIR Conference on Workplace Issues at the London School of Economics, March 14-15, 2008.

${ }^{2}$ Data from the 2003 employee portion of the WES was used in this analysis. The WES follows workers for 2 years and workplaces for six years. As such, the WES 2003 is an independent sample and is representative of the survey population of workers while the workers used in the WES 2004 represent those workers who were selected in 2003 and remained with the workplace in 2004.

${ }^{3}$ There are a range of selection issues that it would be desirable to address, such as selection from the public sector into the private sector; or simply into the labour market itself. We could not find a suitable instrument to use in order to carry out this cross-country analysis. This was an especial constraint for the single wave of data available with the WERS. Not being able to control for selection limits the comparative statements we can make about our estimated returns when compared to other groups not included in the analysis. Our analysis is therefore restricted to the samples of private sector employees we are investigating.

${ }^{4}$ Department of Trade and Industry (2005) Workplace Employment Relations Survey: Cross-Section, 2004 [computer file]. 1st ed. Colchester: The Data Archive [distributor], 21 December 2005. SN: 5294. NB: wave 2 data released in 2007 are used throughout for Britain The authors acknowledge the Department of Trade and Industry, the Economic and Social Research Council, the Advisory, Conciliation and Arbitration Service and the Policy Studies Institute as the originators of the 2004 Workplace Employment Relations Survey data, and the Data Archive at the University of Essex as the distributor of the data. The National Centre for Social Research was commissioned to conduct the survey fieldwork on behalf of the sponsors. None of these organisations bears any responsibility for the author's analysis and interpretations of the data.

${ }^{5}$ The WES contains 500 bootstrap weights for workplaces and employees (Phillips, 2004). In a WES type survey, the bootstrap weights would account for most of the variability incurred at the second-stage. As such, standard errors were computed using the bootstrap weights.

${ }^{6}$ Robustness of the estimation results is of clear concern. The banded nature of the earnings data in the WERS (discussed in Section 3 above) presents an issue for the construction of the earnings series in the analyses presented here. As Stewart (1983) discusses, it is possible, in principle, that this banding may affect the properties of the ordinary least squares estimates of the earnings function that we estimate. Comparison of the estimates presented here with interval estimates confirms they are very similar. We therefore confine our analysis to the more generic estimates presented here.

${ }^{7}$ Estimation by OLS ignores the hierarchical nature of the data and violates the assumption of independence since the disturbances are likely to be correlated for workers in the same workplace (Deaton, 1998; Purdon and Pickering, 2001). The more appropriate error structure 
$\left(\varepsilon_{i j}\right)$ includes a portion varying independently for workers both within and across workplaces, and a portion varying across workplaces but constant for workers in the same workplace. This second portion captures unobserved characteristics at the workplace-level associated with the wages of all workers in the workplace.

${ }^{8}$ The discussion concerning the limits of not having actual work experience for British employees (see Section 3 above) is very pertinent here. It is possible that wage returns to education and age, even for those females who are currently employed full-time, are affected because the employee has had time out of the labour market (or worked less time as a parttime employee) during some part of their career. The results need to be interpreted with this caveat in mind.

${ }^{9}$ It should also be noted that these workplace specific effects may partially capture unobserved worker heterogeneity and this heterogeneity may vary systematically across workplaces.

10 To provide a reliable estimate of the workplace effect in the WES data, waves of independent worker data (1999, 2001, 2003 and 2005) were combined with workplace data in order to maximize the number of responding workers per workplace. Fixed firm effects for men and women were estimated from 61,912 observations in 3,935 workplaces. The average number of responding workers was 15.7 with 7.3 female and 8.4 male respondents. The resulting gender wage gap is slightly lower (21.2 log points versus $23.3 \mathrm{log}$ points in the 2003 data) although not statistically significantly so. As such, the qualitative conclusions remain. 


\section{Appendix.}

Table A1. Variable definitions

\begin{tabular}{|c|c|c|c|}
\hline \multicolumn{2}{|r|}{ Britain } & \multicolumn{2}{|c|}{ Canada } \\
\hline Variable Name & Definition & Variable name & Definition \\
\hline Average hourly pay & $\begin{array}{l}\text { Ratio of (the midpoints of the banded } \\
\text { measure of) weekly average gross } \\
\text { usual earnings (including overtime) and } \\
\text { usual hours worked (including overtime } \\
\text { and extra hours) per week. }\end{array}$ & Average hourly pay & Average hourly pay \\
\hline log average hourly pay & The natural log of average hourly pay & log average hourly pay & $\begin{array}{l}\text { The natural log of average } \\
\text { hourly pay }\end{array}$ \\
\hline Training & $\begin{array}{l}\text { Days of training in last } 12 \text { months } \\
\text { (apart from health and safety) paid for } \\
\text { or organised by the employer }\end{array}$ & Training & $\begin{array}{l}\text { Days of training in last } 12 \\
\text { months }\end{array}$ \\
\hline Education & & Education & \\
\hline None/Other & $\begin{array}{l}\text { Doesn't have a recognised academic } \\
\text { qualifications (May have other } \\
\text { academic qualifications but doesn't } \\
\text { have a listed recognised qualification) }\end{array}$ & None/Other & Below high school \\
\hline $\begin{array}{c}\text { Intermediate } \\
\text { secondary (lower) }\end{array}$ & $\begin{array}{l}\text { cse25: Has general certificate of } \\
\text { secondary education (GCSE) grades } \\
\text { D-G; certificate of education (CSE) } \\
\text { grades 2-5 Scottish certificate of } \\
\text { education (SCE); ordinary (O) level } \\
\text { grades D-; Scottish certificate of } \\
\text { education (SCE) Standard grades 4-7 }\end{array}$ & High school graduate & High school graduate \\
\hline $\begin{array}{c}\text { Intermediate } \\
\text { secondary (upper) }\end{array}$ & $\begin{array}{l}\text { cse1: Has general certificate of } \\
\text { secondary education (GCSE) grades } \\
\text { A-C; general certificate of education } \\
\text { (GCE) ordinary (O) level passes; } \\
\text { certificate of education (CSE) grade } 1 \\
\text { Scottish certificate of education (SCE); } \\
\text { ordinary (O) level grades A-C; or } \\
\text { Scottish certificate of education (SCE) } \\
\text { Standard 1-3 }\end{array}$ & Trade or technical school & Trade or technical school \\
\hline $\begin{array}{l}\text { Higher secondary } \\
\quad \text { (lower) }\end{array}$ & $\begin{array}{l}\text { gceae : Has general certificate of } \\
\text { education (GCE) advanced ( A-level) } \\
\text { grades A-E; 1-2 Scottish certificate of } \\
\text { education (SCE); Higher grades A-C, } \\
\text { As levels }\end{array}$ & Some post secondary & Some post secondary \\
\hline $\begin{array}{l}\text { Higher secondary } \\
\text { (upper) }\end{array}$ & $\begin{array}{l}\text { gce2ae : Has } 2 \text { or more general } \\
\text { certificate of education (GCE) } \\
\text { advanced ( A-level) grades A-E; } 3 \text { or } \\
\text { more Scottish certificate of education } \\
\text { (SCE); or Higher grades A-C }\end{array}$ & College diploma & College diploma \\
\hline Degree & $\begin{array}{l}\text { Has a first degree, eg BSc, BA, HND, } \\
\text { HNC Ma at first degree level }\end{array}$ & University degree & University degree \\
\hline Post graduate & $\begin{array}{l}\text { Has a higher degree, eg MSc, MA, } \\
\text { PGCE, PhD }\end{array}$ & Post graduate degree & Post graduate degree \\
\hline Female & Female & Female & Female \\
\hline child 0-18 & Dependent child aged below 18 & Dependent children & $\begin{array}{l}\text { Dependent child aged below } \\
18\end{array}$ \\
\hline
\end{tabular}




\begin{tabular}{|c|c|c|c|}
\hline child 0-4 & Youngest dependent child aged 0-4 & child $0-4$ & $\begin{array}{l}\text { Youngest dependent child } \\
\text { aged 0-4 }\end{array}$ \\
\hline child 5-11 & Youngest dependent child aged 5-11 & child 5-11 & $\begin{array}{l}\text { Youngest dependent child } \\
\text { aged 5-11 }\end{array}$ \\
\hline child $12-18$ & Youngest dependent child aged 12-18 & child 12-18 & $\begin{array}{l}\text { Youngest dependent child } \\
\text { aged 12-18 }\end{array}$ \\
\hline Married & Married or living with a partner & Married & $\begin{array}{l}\text { Married or living with a } \\
\text { partner }\end{array}$ \\
\hline \multirow[t]{2}{*}{ Disabled } & $\begin{array}{l}\text { Has a long term (expected to last more } \\
\text { than } 1 \text { year) illness or disability. }\end{array}$ & Disabled & $\begin{array}{l}\text { Has difficulty hearing, } \\
\text { seeing, communicating, } \\
\text { walking, climbing stairs, } \\
\text { bending, learning or doing } \\
\text { any similar activities }\end{array}$ \\
\hline & Britain & Canada & \\
\hline Visible minority & $\begin{array}{l}\text { Employee considers they are white } \\
\text { and black Caribbean; white and black } \\
\text { African; white and Asian; any other } \\
\text { mixed background; Indian; Pakistani; } \\
\text { Bangladeshi; any other Asian } \\
\text { background; Caribbean; African; any } \\
\text { other black background; Chinese; or } \\
\text { any other ethnic group. }\end{array}$ & Visible minority & $\begin{array}{l}\text { Canadians come from many } \\
\text { ethnic, cultural and racial } \\
\text { backgrounds. From which } \\
\text { groups did your parents or } \\
\text { grandparents descend? } \\
\text { If Arab, Black, Chinese, } \\
\text { East Indian, Inuit, Japanese, } \\
\text { Korean, Latin America, } \\
\text { Metis, North American } \\
\text { Indian, North African, South } \\
\text { east Asia, West Asian, or } \\
\text { Other }\end{array}$ \\
\hline permanent contract & Employed on a permanent contract. & permanent contract & $\begin{array}{l}\text { Regular employee with no } \\
\text { contractual or anticipated }\end{array}$ \\
\hline part time & $\begin{array}{l}\text { Working part time, if usual working } \\
\text { hours is less than } 30 \text { per week }\end{array}$ & part time & $\begin{array}{l}\text { Usual hours less than or } \\
\text { equal to } 30 \text { per week }\end{array}$ \\
\hline Trade union & $\begin{array}{l}\text { Worker is a member of trade union or } \\
\text { staff association }\end{array}$ & Union & $\begin{array}{l}\text { Worker is unionized or } \\
\text { covered by a CBA }\end{array}$ \\
\hline Tenure & Years working at this workplace & Tenure & $\begin{array}{l}\text { Years working at this } \\
\text { workplace }\end{array}$ \\
\hline Occupation & & Occupation & \\
\hline managerial & Managerial & Managers & \\
\hline Professional & Professional & Professionals & \\
\hline Technical & Technical & Technical / trade & \\
\hline Clerical & Clerical & $\begin{array}{l}\text { Clerical and } \\
\text { administrative }\end{array}$ & \\
\hline craft & Craft service & Marketing and Sales & \\
\hline personal & Personal service & Production & \\
\hline sales & Sales and customer services & & \\
\hline operative & Operative and assembly workers & & \\
\hline unskilled & Unskilled & & \\
\hline
\end{tabular}

Sources: British Workplace Employee Relations Survey 2004 and the Canadian Workplace and Employee Survey 2003. 


\begin{tabular}{|c|c|c|c|c|c|c|c|c|c|}
\hline & & Total & & & Nomen & & & Men & \\
\hline & all & women & men & $<40$ & $40-49$ & $>50$ & $<40$ & $40-49$ & $>50$ \\
\hline log hourly wage & 2.088 & 1.952 & 2.199 & 1.949 & 2.005 & 1.907 & 2.117 & 2.342 & 2.227 \\
\hline age & 39.684 & 38.773 & 40.418 & 28.664 & 45.000 & 56.139 & 29.783 & 45.000 & 56.776 \\
\hline training & 2.311 & 2.184 & 2.417 & 2.408 & 2.150 & 1.693 & 2.758 & 2.278 & 1.884 \\
\hline education not recognised. & 0.247 & 0.226 & 0.264 & 0.086 & 0.245 & 0.532 & 0.120 & 0.256 & 0.549 \\
\hline Intermediate secondary lower & 0.105 & 0.102 & 0.107 & 0.118 & 0.118 & 0.050 & 0.140 & 0.121 & 0.031 \\
\hline Intermediate secondary upper & 0.257 & 0.301 & 0.220 & 0.332 & 0.313 & 0.217 & 0.259 & 0.238 & 0.128 \\
\hline Higher secondary lower & 0.052 & 0.060 & 0.046 & 0.067 & 0.056 & 0.046 & 0.054 & 0.043 & 0.035 \\
\hline Higher secondary upper & 0.092 & 0.099 & 0.085 & 0.131 & 0.085 & 0.037 & 0.106 & 0.075 & 0.056 \\
\hline degree & 0.180 & 0.155 & 0.201 & 0.211 & 0.114 & 0.065 & 0.242 & 0.199 & 0.123 \\
\hline postgraduate & 0.052 & 0.040 & 0.062 & 0.042 & 0.051 & 0.026 & 0.069 & 0.058 & 0.052 \\
\hline oldest dep. child 0-4 & 0.124 & 0.096 & 0.148 & 0.163 & 0.031 & 0.003 & 0.235 & 0.117 & 0.009 \\
\hline oldest dep. child 5-11 & 0.128 & 0.120 & 0.134 & 0.141 & 0.187 & 0.004 & 0.115 & 0.284 & 0.036 \\
\hline oldest dep. child 12-18 & 0.109 & 0.114 & 0.104 & 0.039 & 0.318 & 0.088 & 0.028 & 0.249 & 0.121 \\
\hline married & 0.651 & 0.634 & 0.665 & 0.543 & 0.734 & 0.748 & 0.532 & 0.766 & 0.829 \\
\hline disabled & 0.112 & 0.098 & 0.123 & 0.070 & 0.104 & 0.156 & 0.066 & 0.139 & 0.218 \\
\hline visible minority & 0.064 & 0.059 & 0.068 & 0.068 & 0.059 & 0.036 & 0.098 & 0.042 & 0.032 \\
\hline permanent & 0.928 & 0.925 & 0.930 & 0.901 & 0.956 & 0.950 & 0.911 & 0.962 & 0.937 \\
\hline union member & 0.207 & 0.177 & 0.231 & 0.133 & 0.236 & 0.221 & 0.165 & 0.295 & 0.300 \\
\hline tenure & 4.827 & 4.515 & 5.084 & 3.363 & 5.309 & 6.409 & 3.924 & 5.981 & 6.505 \\
\hline female & 0.450 & 1.000 & 0.000 & 1.000 & 1.000 & 1.000 & 0.000 & 0.000 & 0.000 \\
\hline part time & 0.223 & 0.386 & 0.089 & 0.345 & 0.394 & 0.471 & 0.100 & 0.046 & 0.106 \\
\hline managerial & 0.139 & 0.101 & 0.169 & 0.098 & 0.128 & 0.083 & 0.137 & 0.223 & 0.184 \\
\hline professional & 0.081 & 0.050 & 0.106 & 0.058 & 0.044 & 0.038 & 0.110 & 0.105 & 0.100 \\
\hline technical & 0.125 & 0.137 & 0.116 & 0.154 & 0.143 & 0.094 & 0.131 & 0.119 & 0.084 \\
\hline clerk & 0.165 & 0.271 & 0.077 & 0.251 & 0.262 & 0.328 & 0.084 & 0.062 & 0.079 \\
\hline craft & 0.090 & 0.016 & 0.150 & 0.014 & 0.022 & 0.016 & 0.145 & 0.163 & 0.149 \\
\hline personal & 0.048 & 0.086 & 0.018 & 0.087 & 0.081 & 0.087 & 0.019 & 0.016 & 0.017 \\
\hline sales & 0.118 & 0.187 & 0.061 & 0.208 & 0.159 & 0.164 & 0.092 & 0.028 & 0.033 \\
\hline operative & 0.108 & 0.039 & 0.165 & 0.030 & 0.052 & 0.046 & 0.135 & 0.188 & 0.201 \\
\hline unskilled & 0.126 & 0.113 & 0.137 & 0.101 & 0.109 & 0.144 & 0.147 & 0.097 & 0.155 \\
\hline Sample size & 14272 & 6790 & 7464 & 3613 & 1624 & 1553 & 3615 & 1887 & 1962 \\
\hline
\end{tabular}

Note: Young refers to workers less than 40 years of age; Prime-aged refers to workers aged 40-49; Mature workers refers to those aged 50+ Source: British Workplace Employee Relations Survey 2004. 
Table A3: Characteristics of the Canadian private sector workforce, Workplace and Employee Survey 2003

\begin{tabular}{|c|c|c|c|c|c|c|c|c|}
\hline \multirow[b]{2}{*}{ Variable } & \multirow[b]{2}{*}{ Men } & \multirow[b]{2}{*}{ Women } & \multicolumn{3}{|c|}{ Women } & \multicolumn{3}{|c|}{ Men } \\
\hline & & & $<40$ & $40-49$ & $50+$ & $<40$ & $40-49$ & $50+$ \\
\hline log hourly wage & 3.030 & 2.797 & 2.696 & 2.871 & 2.901 & 2.887 & 3.146 & 3.173 \\
\hline hourly wage \$canadian & 23.70 & 18.57 & 16.71 & 19.95 & 20.42 & 20.53 & 25.87 & 27.35 \\
\hline age & 40.419 & 39.972 & 29.632 & 44.434 & 55.235 & 30.286 & 44.505 & 55.542 \\
\hline age_squared & 1.767 & 1.727 & 0.916 & 1.982 & 3.069 & 0.955 & 1.989 & 3.107 \\
\hline Training time & 2.150 & 2.296 & 2.710 & 1.803 & 2.170 & 2.400 & 2.347 & 1.420 \\
\hline Below high school & 0.119 & 0.079 & 0.071 & 0.064 & 0.120 & 0.109 & 0.101 & 0.162 \\
\hline High School graduate & 0.181 & 0.162 & 0.125 & 0.190 & 0.196 & 0.200 & 0.179 & 0.148 \\
\hline Trade school & 0.141 & 0.068 & 0.044 & 0.086 & 0.092 & 0.102 & 0.169 & 0.183 \\
\hline Some post secondary & 0.134 & 0.169 & 0.196 & 0.142 & 0.152 & 0.150 & 0.120 & 0.119 \\
\hline College & 0.178 & 0.263 & 0.282 & 0.285 & 0.188 & 0.197 & 0.185 & 0.131 \\
\hline University & 0.165 & 0.175 & 0.201 & 0.151 & 0.155 & 0.180 & 0.159 & 0.143 \\
\hline Post-graduate & 0.061 & 0.061 & 0.065 & 0.057 & 0.059 & 0.051 & 0.063 & 0.081 \\
\hline unknown education & 0.020 & 0.023 & 0.016 & 0.025 & 0.037 & 0.011 & 0.024 & 0.033 \\
\hline Has dependent children & 0.440 & 0.396 & 0.406 & 0.575 & 0.098 & 0.420 & 0.656 & 0.219 \\
\hline$\ldots 4$ years or less & 0.164 & 0.093 & 0.184 & 0.026 & $\ldots$ & 0.267 & 0.120 & $\ldots$ \\
\hline$\ldots$ aged $5-11$ & 0.148 & 0.151 & 0.173 & 0.210 & $\ldots$ & 0.128 & 0.269 & $\ldots$ \\
\hline$\ldots$ aged $12-18$ & 0.127 & 0.152 & 0.049 & 0.339 & $\ldots$ & 0.026 & 0.267 & 0.160 \\
\hline Married & 0.720 & 0.645 & 0.561 & 0.733 & 0.689 & 0.583 & 0.835 & 0.852 \\
\hline Disability & 0.105 & 0.080 & 0.046 & 0.092 & 0.133 & 0.085 & 0.105 & 0.144 \\
\hline Ethnic & 0.089 & 0.090 & 0.094 & 0.091 & 0.079 & 0.101 & 0.075 & 0.082 \\
\hline Permanent & 0.962 & 0.976 & 0.974 & 0.976 & 0.980 & 0.962 & 0.982 & 0.940 \\
\hline Part-time & 0.069 & 0.216 & 0.246 & 0.181 & 0.207 & 0.092 & 0.035 & 0.065 \\
\hline Tenure-years & 6.766 & 6.468 & 5.108 & 7.329 & 8.053 & 5.491 & 7.714 & 8.147 \\
\hline Unionized & 0.275 & 0.279 & 0.193 & 0.331 & 0.385 & 0.213 & 0.327 & 0.333 \\
\hline Managers & 0.165 & 0.087 & 0.070 & 0.106 & 0.092 & 0.125 & 0.166 & 0.242 \\
\hline Professionals & 0.130 & 0.203 & 0.186 & 0.197 & 0.247 & 0.132 & 0.131 & 0.126 \\
\hline Technical Trade & 0.522 & 0.313 & 0.319 & 0.309 & 0.309 & 0.510 & 0.560 & 0.502 \\
\hline Clerical Admin & 0.072 & 0.218 & 0.209 & 0.240 & 0.201 & 0.084 & 0.065 & 0.057 \\
\hline Marketing Sales & 0.033 & 0.117 & 0.150 & 0.102 & 0.070 & 0.049 & 0.018 & 0.019 \\
\hline Production & 0.077 & 0.062 & 0.065 & 0.045 & 0.080 & 0.100 & 0.060 & 0.054 \\
\hline Observations & 10,595 & 8,242 & 3,629 & 2,820 & 1,793 & 4,420 & 3,411 & 2,764 \\
\hline
\end{tabular}

Note: Young refers to workers less than 40 years of age; Prime-aged refers to workers aged 40-49; Mature

workers refers to those aged $50+$. Notation ... number too small to report

Source: Canadian Workplace and Employee Survey 2003. 